\title{
Acute Ischemic Stroke in a Patient with a Native Valvular Strand
}

\author{
Hak Young Rhee ${ }^{\mathrm{a}}$ Hye-Yeon Choi ${ }^{\mathrm{a}}$ Sang-Beom Kim ${ }^{\mathrm{a}}$ \\ Won-Chul Shin ${ }^{\mathrm{a}}$ Sung Hun Kim ${ }^{\mathrm{b}}$ \\ ${ }^{a}$ Department of Neurology, Kyung Hee University East-West Neo Medical Center, \\ Seoul, and ${ }^{\mathrm{b}}$ Department of Neurology, College of Medicine, Kangwon National \\ University, Chuncheon, Republic of Korea
}

\section{Key Words}

Acute ischemic stroke - Antiplatelet treatment - Cardioembolism - Stroke mechanisms . Valvular strands · Lambl's excrescences

\begin{abstract}
Valvular strands are known to be a potential source of cardioembolism but the natural history of native valvular strands has not yet been fully outlined. We report a case of ischemic stroke in a patient with a native valvular strand of the aortic valve and the patient's clinical course. A previously healthy 21 -year-old man suffered acute cerebral infarction in the right posterior cerebral artery territory. On echocardiography, there was a strand-like, oscillating mass on the left coronary cusp of the aortic valve. The patient received $100 \mathrm{mg}$ aspirin daily and the valvular strand was not found on subsequent transthoracic echocardiography performed 10 days after the first examination. Serial echocardiographic examinations have been performed since the stroke and failed to find any abnormality. The patient did not suffer a recurrent stroke over a 3-year follow-up period.
\end{abstract}

\section{Introduction}

The diagnosis of valvular strands is based on echocardiographic findings of thin, mobile, filiform structures most often occurring on the ventricular side of the aortic valve and on the atrial side of the mitral valve. They are known to be a potential source of cardioembolism but there are no definite recommendations about the management [1-3]. Moreover, the natural history of native valvular strands has not yet been fully outlined. Here, we describe a case of ischemic stroke in a patient with a native valvular strand on the aortic valve and the patient's clinical course. 


\begin{tabular}{l|l|l|l}
$\begin{array}{c}\text { Case Reports in } \\
\text { Neurology }\end{array}$ & $\begin{array}{l}\text { Case Rep Neurol 2010;2:91-95 } \\
\text { D0l: } 10.1159 / 000317117\end{array}$ & Published online: June 25, 2010 & $\begin{array}{l}\odot \text { 2010 S. Karger AG, Basel } \\
\text { ISSN 1662-680X } \\
\text { www.karger.com/crn }\end{array}$ \\
\hline
\end{tabular}

\section{Case Report}

A 21-year-old man without any prior medical history developed sudden left-sided paresthesia. Neurological examination revealed left homonymous hemianopia as well as hypesthesia on the left side of the body. Diffusion-weighted magnetic resonance imaging (MRI) of the brain, which was performed 1 day after the onset of symptoms, showed high signal intensities in the right thalamus and temporooccipital gyrus corresponding to the territory of the right posterior cerebral artery (PCA, fig. 1a, b). MR angiography demonstrated no abnormal findings in the cerebral arteries except a short focal area of signal dropout at the right P2 PCA (fig. 1c). Complete blood counts, routine chemistry, and thyroid function tests were all normal. Blood tests performed to screen for autoimmune and coagulation diseases were all negative or within normal limits. Holter monitoring showed no specific findings, but transthoracic echocardiography (TTE) and transesophageal echocardiography (TEE) showed a strandlike, oscillating mass on the left coronary cusp (fig. 2). The patient received $100 \mathrm{mg}$ aspirin daily and open heart surgery was planned for resection of the valvular mass. However, the mass was not observed on follow-up echocardiographic examinations which were performed 10 days after the first examination. Serial TTEs were performed 3, 6, and 21 months after the stroke and the last TTE was performed 3 years after the stroke. These failed to find any abnormality. The patient received $100 \mathrm{mg}$ aspirin daily for 2 years and has not suffered any other strokes thus far during the 3-year follow-up period after the stroke.

\section{Discussion}

Valvular strands are thin, mobile, thread-like structures attached to the cardiac valves which are visualized by echocardiogram. Various pathological conditions have been reported as valvular strands on the cardiac valves, including papilloma, papillary fibroma, fibroelastoma, and Lambl's excrescences. It is most difficult to distinguish between Lambl's excrescences and fibroelastoma [4]. 'Lambl's excrescences' is the term used to describe papillary intracardiac structures that usually arise from the valvular closure line and contain a fibroelastic core covered by a single layer of endothelial tissue.

Fibroelastomas are different from Lambl's excrescences in terms of location, shape, and size. They usually arise from the midportion of the valve leaflets and are often pedunculated and more bulky. Furthermore, their surface contains multiple, small, finger-like projections [5]. Histologically, fibroelastomas have multiple layers of endothelial cells while Lambl's excrescences are covered only by a single layer of endothelial cells [6]. Hence, in this case, it is impossible to specifically diagnose the mass as a Lambl's excrescence or a fibroelastoma solely based on echocardiographic findings. The valvular strand would need to be examined histologically to make that determination. However, it is assumed that any echocardiographically-detected valvular strands likely represent Lambl's excrescences [7].

This case raises two important issues about stroke occurring in patients with valvular strands. First, the association of valvular strands with systemic embolization is somewhat confusing. Several studies have shown the etiologic role of strands on both native and prosthetic valves $[3,8,9]$. It is hypothesized that a part of the strands or a thrombus formed on the strand's surface embolizes to distant organs, although there is a lack of pathological evidence for this mechanism. Our patient was young and previously healthy and we did not find any other potential cause of the stroke except for the valvular strand of the aortic valve detected by echocardiography. This suggests the possibility that the valvular strand contributed to the development of cardioembolic cerebral infarction.

Second, the strand was not found on serial echocardiographic examinations during the 3-year follow-up period. Because we performed TTEs, there is a possibility that the strand has not been detected. But it is also possible that the strand has disappeared after antiplatelet therapy. In fact, not much is known about the natural history and the change 


\begin{tabular}{c|l|l|l}
$\begin{array}{c}\text { Case Reports in } \\
\text { Neurology }\end{array}$ & $\begin{array}{l}\text { Case Rep Neurol 2010;2:91-95 } \\
\text { D0I: } 10.1159 / 000317117\end{array}$ & Published online: June 25, 2010 & $\begin{array}{l}\odot \text { 2010 S. Karger AG, Basel } \\
\text { ISSN 1662-680X } \\
\text { www.karger.com/crn }\end{array}$ \\
\hline
\end{tabular}

after medical management of valvular strands. The strands on a prosthetic mitral valve often undergo spontaneous resolution, which may be related to intrinsic fibrinolytic activity or to dislodgment. But in cases of native valvular strands, it has been suggested that they are persistent and may reflect a long-term change in heart valves [10]. However, the 3-month follow-up period in the aforementioned study may have been too short to reflect the exact natural history of this type of valvular strand. The initiating event of formation of Lambl's excrescences may be small tears of the endocardial surface [11]. In this case, it is possible that the initial growth of thrombi was inhibited and subsequently resolved with treatment with an antiplatelet agent. A similar case has been reported in a patient with prosthetic valvular strands on the mitral valve which resolved with the use of dipyridamole [8].

There are several treatment options for the management of valvular strands in patients with ischemic stroke; however, the best treatment modality to prevent stroke recurrence has not been fully established. In some instances, it seems reasonable to perform surgical resection in patients who are refractory to medical therapy with antiplatelet agents or oral anticoagulants. Fibroelastomas may require surgical resection in symptomatic patients because they are larger and more prone to embolization $[4,13]$. For medical therapeutic options, there was no significant difference in treatment efficacy between aspirin and warfarin in a randomized, double-blind trial of medical treatment in patients with cryptogenic stroke and valvular strands [1]. Until now, a generalized treatment strategy has not been established and therapy for symptomatic valvular strands should be individualized according to the patient's status.

We report a patient with ischemic stroke probably due to a native valvular strand, who did not have a detectable strand on follow-up examination and a favorable prognosis for at least 3 years after the initial event.

Fig. 1. Diffusion-weighted axial MRI shows multifocal diffusion restricted lesions in the right thalamus and temporo-occipital areas $(\mathbf{a}, \mathbf{b})$. MR angiography depicts a short focal area of signal drop-out at the right P2 PCA ( arrow, c).
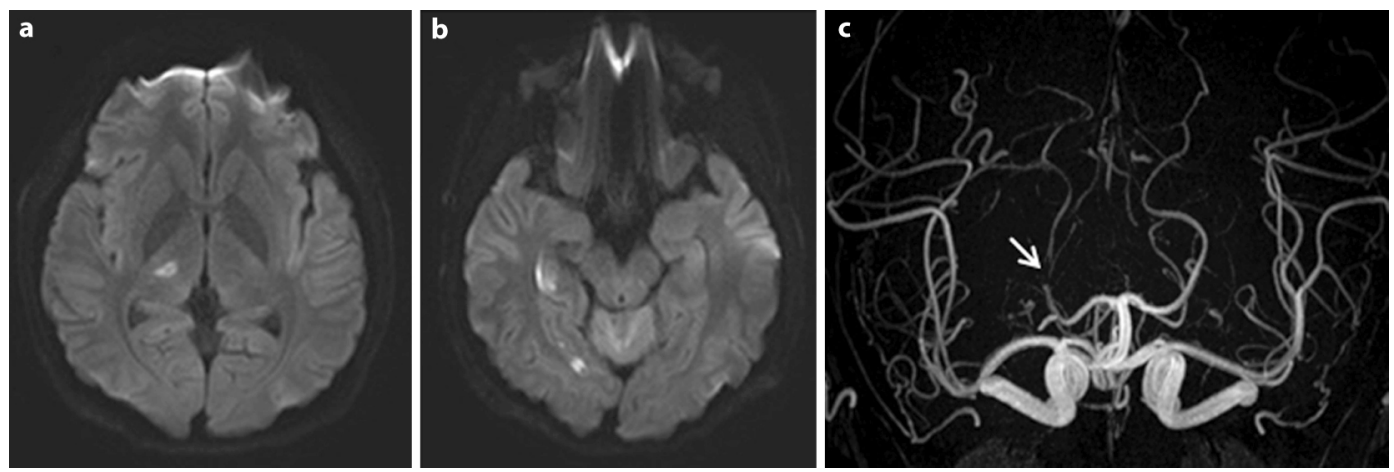


\begin{tabular}{l|l|l|l}
$\begin{array}{c}\text { Case Reports in } \\
\text { Neurology }\end{array}$ & $\begin{array}{l}\text { Case Rep Neurol 2010;2:91-95 } \\
\text { D0I: 10.1159/000317117 }\end{array}$ & Published online: June 25, 2010 & $\begin{array}{l}\text { O 2010 S. Karger AG, Basel } \\
\text { ISSN 1662-680X } \\
\text { www.karger.com/crn }\end{array}$ \\
\hline
\end{tabular}

Fig. 2. A strand-like, oscillating mass on the left coronary cusp is seen in the long axis view of the aortic valve on TTE (arrow head, a) and TEE (arrow, b).
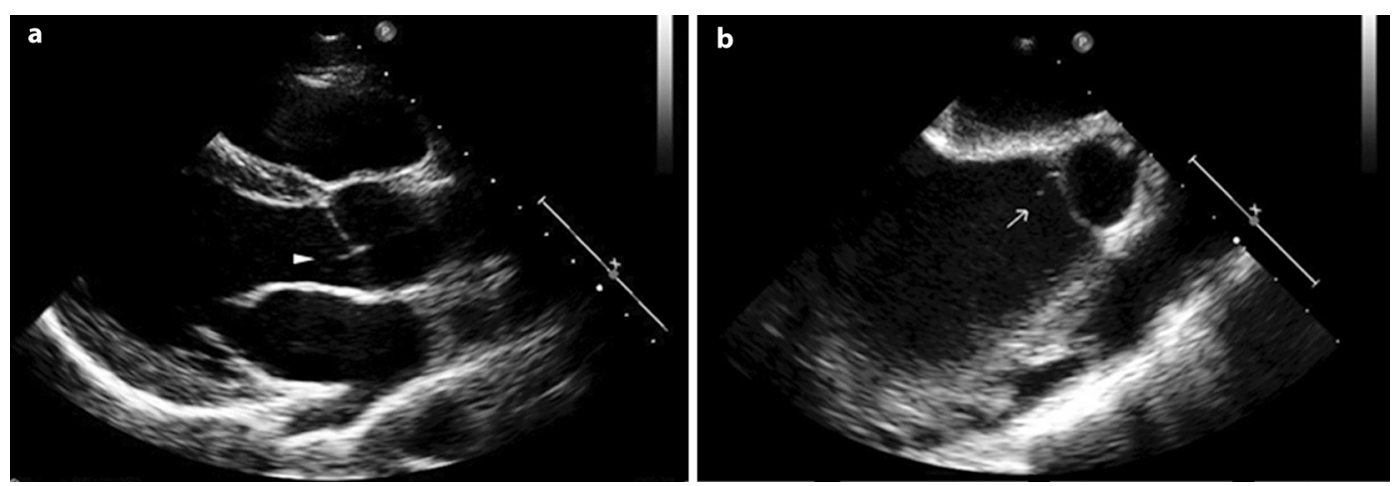


\begin{tabular}{c|l|l|l}
$\begin{array}{c}\text { Case Reports in } \\
\text { Neurology }\end{array}$ & $\begin{array}{l}\text { Case Rep Neurol 2010;2:91-95 } \\
\text { D01: } 10.1159 / 000317117\end{array}$ & & $\begin{array}{l}\text { Published online: June 25, 2010 S. Karger AG, Basel } \\
\text { ISSN 1662-680X } \\
\text { www.karger.com/crn }\end{array}$ \\
\hline
\end{tabular}

\section{References}

$\checkmark 1$ Homma S, Di Tullio MR, Sciacca RR, Sacco RL, Mohr JP; PICSS Investigators: Effect of aspirin and warfarin therapy in stroke patients with valvular strands. Stroke 2004;35:1436-1442.

-2 Cohen A, Tzourio C, Chauvel C, Bertrand B, Crassard I, Bernard Y, Goullard L, Falcon S, Bousser MG, Amarenco P: Mitral valve strands and the risk of ischemic stroke in elderly patients. The French Study of Aortic Plaques in Stroke (FAPS) Investigators. Stroke 1997;28:1574-1578.

-3 Freedberg RS, Goodkin GM, Perez JL, Tunick PA, Kronzon I: Valve strands are strongly associated with systemic embolization: a transesophageal echocardiographic study. J Am Coll Cardiol 1995;26:1709-1712.

4 Gowda RM, Khan IA, Nair CK, Mehta NJ, Vasavada BC, Sacchi TJ: Cardiac papillary fibroelastoma: a comprehensive analysis of 725 cases. Am Heart J 2003;146:404-410.

5 Daveron E, Jain N, Kelley GP, Luer WH, Fermin C, Helmcke F, Kerut EK: Papillary fibroelastoma and Lambl's excrescences: echocardiographic diagnosis and differential diagnosis. Echocardiography 2005;22:461-463.

-6 Fishbein MC, Ferrans VJ, Roberts WC: Endocardial papillary elastofibromas. Histologic, histochemical, and electron microscopical findings. Arch Pathol 1975;99:335-341.

7 Voros S, Nanda NC, Thakur AC, Winokur TS, Samal AK: Lambl's excrescences (valvular strands). Echocardiography 1999;16:399-414.

-8 Orsinelli DA, Pearson AC: Detection of prosthetic valve strands by transesophageal echocardiography: clinical significance in patients with suspected cardiac source of embolism. J Am Coll Cardiol 1995;26:1713-1718.

-9 Lee RJ, Bartzokis T, Yeoh TK, Grogin HR, Choi D, Schnittger I: Enhanced detection of intracardiac sources of cerebral emboli by transesophageal echocardiography. Stroke 1991;22:734-739.

10 Nighoghossian N, Derex L, Perinetti M, Honnorat J, Barthelet M, Loire R, Adeleine P, Dayoub MG, Servan E, Moreau T, Confavreux C, Ryvlin P, Mauguière F, Hernette D, Broussolle E, Chazot G, Tiliket C, Vighetto A, Riche G, Bourrat C, Trouillas P: Course of valvular strands in patients with stroke: cooperative study with transesophageal echocardiography. Am Heart J 1998;136:1065-1069.

11 Pomerance A: Papillary 'tumours' of the heart valves. J Pathol Bacteriol 1961;81:135-140.

12 Nighoghossian N, Trouillas P, Perinetti M, Barthelet M, Ninet J, Loire R: Lambl's excrescence: an uncommon cause of cerebral embolism (in French). Rev Neurol (Paris) 1995;151:583-585.

13 Giannesini C, Kubis N, N’Guyen A, Wassef M, Mikol J, Woimant F: Cardiac papillary fibroelastoma: a rare cause of ischemic stroke in the young. Cerebrovasc Dis 1999;9:45-49. 